\title{
Problems with the new born screen for galactosaemia
}

\author{
John I Malone, Alicia Diaz-Thomas, Kathleen Swan \\ Department of Pediatrics, University of South Florida, Tampa, Florida, USA \\ Correspondence to Professor John I Malone, jmalone@hsc.usf.edu
}

\begin{abstract}
Summary
The new born screen should identify asymptomatic children with a devastating disorder before the damage has occurred. One family had two children born with classical galactosaemia. The first child, subject to a flaw in the newborn screening program, was not detected, went into rapid liver failure and ultimately had a liver transplant. The second child was following the same devastating course when identified by the new born screen with reduced galactose-1-phosphate uridyl transferase activity in a blood spot. The rapid response of the second child to removal of lactose and galactose from the diet resulted in significant clinical improvement. If the screening test for an inborn genetic defect involves the measurement of enzyme activity in red blood cells, be sure the patient has only native red blood cells. The events leading to the failure of the galactosaemia screening test are reviewed, so physicians will be aware and avoid this problem.
\end{abstract}

\section{BACKGROUND}

The newborn screen is a practice of testing every newborn for harmful or fatal genetic disorders before they are clinically manifest. Early intervention for these problems prevents morbidity and mortality. Classical galactosaemia ${ }^{1}$ is a genetically determined deficiency of the enzyme galactose-1-phosphate uridyl transferase (GALT) activity. This deficiency causes accumulation of galactose, galactose-1phosphate and galactitol in tissues of affected individuals. ${ }^{1}$ The primary source of galactose is lactose, found in mammalian milk. Newborn infants are immediately exposed to lactose in human milk and most infant formulas. The clinical signs of this defect (feeding problems, hepatomegaly, jaundice, failure to thrive, cataracts, hypoglycaemia, gram negative sepsis and acute liver failure $)^{1}$ become evident during the neonatal period. Liver failure and gram negative sepsis have resulted in death. ${ }^{2}$ A common screening method for galactosaemia is the Beutler fluorometric assay ${ }^{3}$ which measures GALT activity in blood spots collected on filter paper. Reduced florescence indicates reduced or absent GALT activity. This may identify a genetic defect or deterioration of enzyme activity before analysis. Thus, the screening test only identifies subjects at risk. Diagnostic tests are essential for the correct diagnosis. We report one family's experience with the newborn screen and a problem paediatricians should understand and avoid.

\section{CASE PRESENTATION}

Patient A was a 3240 g vigorous female born by spontaneous vaginal delivery at 39 weeks gestation. Initial feedings were breast milk and the new born screening blood was collected at $34 \mathrm{~h}$ of age. On day 5 , a liver function test was performed because a sibling (patient B) had been diagnosed with liver failure attributed to neonatal haemochromatosis. Patient A had evidence of early liver disease (table 1). It was assumed to be neonatal haemochromatosis and she was transferred to the hospital where patient $B$ had a liver transplant 4 years earlier at 9 weeks of age. Prior to physicians seeing the newborn screen report, patient
A had intravenous immunoglobulin and two exchange transfusions administered for neonatal haemochromatosis. Simultaneously, the diet was changed to pregestimil, a cow milk formula with lactose removed. This initial treatment completely corrected her liver function tests and she was taken off the transplant list. The infant screen reported reduced GALT activity $<2.1 \mathrm{U} / g$ Hgb but reliable confirmatory testing could not be performed because of the exchange transfusions. Since liver function improved in response to exclusion of lactose from the diet, further evaluation for galactosaemia by measuring urinary galactitol $^{4}$ was not pursued. At 6 months of age, red cell GALT activity was undetected; sequence analysis of the GALT gene showed two mutations, Q188R/Y209C, consistent with classical galactosaemia.

Patient B had a clinical course with certain similarities. She was born at 37 weeks gestation weighing $3107 \mathrm{~g}$. She was breast fed and her newborn screen at $48 \mathrm{~h}$ showed a GALT activity of $1.9 \mathrm{U} / \mathrm{g} \mathrm{Hgb}$, but the screening laboratory indicated the sample was inadequate and requested a second sample. Before that request was received the child was hospitalised because of poor breast milk feeding and abdominal distension. The hospital course deteriorated with prothrombin time and partial thromboplastin time increasing and total albumin falling to $2.1 \mathrm{~g} / \mathrm{dl}$. Her haemoglobin dropped below $7 \mathrm{~g} / \mathrm{dl}$ (haematocrit $22 \%$ ) and she

Table 1 Patient A liver function

Day 5

Total bilirubin - $21.9 \mathrm{mg} / \mathrm{dl}(0.2-1.2 \mathrm{mg} / \mathrm{dl})$

SGOT - $147 \mathrm{U} / \mathrm{l}(5-34 \mathrm{U} / \mathrm{l})$

SGPT - $106 \mathrm{U} / \mathrm{I}(0-55 \mathrm{U} / \mathrm{l})$

Alkaline phosphatase $1385 \mathrm{U} / \mathrm{l}(40-150 \mathrm{U} / \mathrm{l})$

Day 11

Albumin - $2.7 \mathrm{~g} / \mathrm{dl}(2.9-5.5 \mathrm{~g} / \mathrm{dl})$

PT $-26.5 \mathrm{~s}(10-12.6 \mathrm{~s})$

PTT $->124 \mathrm{~s}(23-39 \mathrm{~s})$

PT, prothrombin time; PTT, partial thromboplastin time; SGOT, serum glutamic oxaloacetic transaminase; SGPT, serum glutamic pyruvic transaminase. 
received a transfusion with packed red blood cells. The rescreen for galactosaemia was collected and sent after the blood transfusion and the report indicated normal GALT activity. Patient B continued to show progressive liver failure and was made NPO (receiving only intravenous fluids) for $12 \mathrm{~h}$ before a liver biopsy. Following the biopsy the child was started on a soy formula. One day later the biopsy report indicated severe cirrhosis with increased iron within macrophages. The most likely aetiologies suggested were: galactosaemia, tyrosinaemia and hereditary fructose intolerance. Urine was then collected for reducing sugar measurement which was negative. Patient B was then transported to another hospital for a liver transplant. The receiving physicians believed that this child had neonatal haemochromatosis. Because of her emaciated appearance, distended abdomen and ascites her enteral feedings were switched to medium-chain triglycerides rich pregestimil. Her appetite started to improve and vomiting decreased. It was also noted at that time that the child had reduced consciousness, seizures and elevated ammonia so lactulose and neomycin were added to her treatment to lower the ammonia. Lactulose is an oral agent containing $15 \%$ galactose used to remove excess ammonia through the intestines. The liver failure continued to progress and a living donor liver transplantation occurred at 9 weeks of age. Patient $B$ recovered from her liver transplantation and was maintained on immunosuppressive medications and enfamil lipil 24 calories/ounce, a lactose containing formula. She was characterised by her mother as a 'picky eater' and had numerous episodes of vomiting and diarrhoea that were attributed to milk protein allergy. Cow milk was removed from her diet.

After patient A was diagnosed with classical galactosaemia, patient B ( 4 years old) had her red cell GALT activity measured for the first time since her transplant. This revealed absent GALT activity. Sequencing of her GALT gene revealed the same two mutations, Q188R/Y209C, found in her younger sibling.

Both children were placed on a low lactose/galactose diet. During a routine follow-up visit a 3-day diet history indicated the older child (5 and 9/12 years) consumed larger portions of the same foods as the younger sibling (1 and 6/12 years); both children consumed approximately 100 calories/kg/day. At that visit, red cell galactose-1-phosphate and urine galactitol in a first morning specimen were measured (table 2). Despite her liver transplant, patient B had an elevated galactose -1- phosphate in her red blood cells, but a lower urinary galactitol than her sibling. The liver transplant has improved galactose metabolism, but has not corrected the galactosaemia, as manifest clinically by recurring episodes of vomiting and diarrhoea in association with dietary lactose.

\section{DISCUSSION}

The initial screening test results for each of these children suggested a defect in GALT activity. In patient A, the confirmatory test was performed after two exchange transfusions; the results indicated normal GALT activity. The progressive liver failure in patient A responded to a lactose-free diet making the clinical diagnosis of galactosaemia likely. Six months after the exchange transfusions, the
Table 2 Galactose metabolism in two children with the same GALT defect but two genetically different livers

\begin{tabular}{llll}
\hline Patient & Weight $(\mathbf{k g})$ & $\begin{array}{l}\text { RBC gal-1-P } \\
(\boldsymbol{\mu g} / \mathbf{g ~ H g b})\end{array}$ & $\begin{array}{l}\text { Urine galactitol } \\
(\boldsymbol{\mu} \mathrm{M} / \mathbf{m M} \text { creatinine })\end{array}$ \\
\hline $\mathrm{A}$ & 9.73 & $74(80-125)$ & $254.6(194-620)$ \\
$\mathrm{B}$ & 18.9 & $94(80-125)$ & $126.7(194-620)$ \\
\hline
\end{tabular}

The reference ranges indicated are for individuals with classical galactosaemia on a lactose-free diet. Normal red cell gal-1-P levels range from 5 to $49 \mu \mathrm{g} / \mathrm{gm}$ $\mathrm{Hbg}$ and normal urine galactitol is $<45.4 \mu \mathrm{M} / \mathrm{mM}$ creatinine. ${ }^{4}$ $\mathrm{RBC}$, red blood cell.

absence of GALT in her blood was confirmed. In patient $\mathrm{B}$, the confirmatory test occurred after the child had one packed red cell transfusion; results indicated normal GALT activity. A test for reducing sugar in the urine provided another false negative result since it was collected more than $48 \mathrm{~h}$ after galactose exposure ended. The next confirmatory test, 4 years later, indicated no GALT activity.

Patient $\mathrm{A}$ is an example of new born screening having a major positive impact upon the life of a child. Concomitantly, patient B exemplifies a pitfall of the newborn screen. Paediatricians must be aware that inappropriate interpretation of results from the new born screen can compromise the test's effectiveness. Galactosaemia is an important congenital defect that should be identified by the newborn screen and should always be considered in cases of neonatal liver failure. This defect is identified by reduced enzyme activity in the patient's red blood cells. Neither screening nor confirmatory testing is valid after a transfusion. If galactosaemia is a consideration, it is prudent to introduce low lactose/galactose soy milk ${ }^{5}$ to the diet until the diagnosis can be confirmed later with the child's native red blood cells.

\section{Learning points}

- Newborn screening tests may prevent the morbidity and mortality associated with inborn errors of metabolism.

- Physicians must understand the screening test results for this approach to be effective.

- A newborn with progressive liver disease must avoid galactose until another aetiology is proven.

\section{Competing interests None.}

Patient consent Obtained.

\section{REFERENCES}

1. Berry GT, Segal S, Gitzelmann R. Disorders of galactose metabolism. In: Fernandes J, van der Berghe G, Walter JH, eds. Inborn Metabolic Diseases Diagnosis and Treatment. Fourth edition. New York, NY: Springer-Verlag, Inc 2006

2. Levy HL, Sepe SJ, Shih VE, et al. Sepsis due to Escherichia coli in neonates with galactosemia. N Engl J Med 1977;297:823-5.

3. Beutler E, Baluda MC. A simple spot screening test for galactosemia. J Lab Clin Med 1966;68:137-41.

4. Ning C, Segal S. Plasma galactose and galactitol concentration in patients with galactose-1-phosphate uridyltransferase deficiency galactosemia: determination by gas chromatography/mass spectrometry. Metab Clin Exp 2000; 49:1460-6.

5. Elsas LJII. Galactosemia. In: Pagon RA, Bird TD, Dolan CR, Stephens K, eds GeneReviews. Seattle, WA: University of Washington 2007:1-21. 


\section{BMJ Case Reports}

This pdf has been created automatically from the final edited text and images.

Copyright 2011 BMJ Publishing Group. All rights reserved. For permission to reuse any of this content visit http://group.bmj.com/group/rights-licensing/permissions.

BMJ Case Report Fellows may re-use this article for personal use and teaching without any further permission.

Please cite this article as follows (you will need to access the article online to obtain the date of publication).

Malone JI, Diaz-Thomas A, Swan K. Problems with the new born screen for galactosaemia. BMJ Case Reports 2011;10.1136/bcr.01.2011.3769, date of publication

Become a Fellow of BMJ Case Reports today and you can:

- Submit as many cases as you like

- Enjoy fast sympathetic peer review and rapid publication of accepted articles

- Access all the published articles

Re-use any of the published material for personal use and teaching without further permission

For information on Institutional Fellowships contact consortiasales@bmjgroup.com

Visit casereports.bmj.com for more articles like this and to become a Fellow 